\title{
A Specific and Sensitive Method for the Detection of Colletotrichum lindemuthianum in Dry Bean Tissue
}

\author{
Yong-Yan Chen, Agriculture and Agri-Food Canada (AAFC), Morden Research Station, Unit 100-101, Route 100, \\ Morden, MB, R6M 1Y5; and College of Bioengineering, Dalian University, Dalian 116622, China; R. L. Conner, \\ AAFC, Morden Research Station, Unit 100-101, Route 100, Morden, MB, R6M 1Y5; C. L. Gillard, Ridgetown \\ Campus of the University of Guelph, 120 Main St. East, Ridgetown, ON, NOP 2C0; G. J. Boland, Department of \\ Environmental Biology, University of Guelph, Guelph, ON, N1G 2W1; C. Babcock, Canadian Collection of Fungal \\ Cultures, AAFC, Room 1015, K.W. Neatby Bldg., Ottawa, ON, K1A OC6; Kan-Fa Chang, Field Crop Development \\ Center, Alberta Agriculture, Food and Rural Development (AAFRD), Lacombe, AB, T4L 1W1; S. F. Hwang, Crop \\ Diversification Centre North, AAFRD, Edmonton, AB, T5Y 6H3; and P. M. Balasubramanian, AAFC, Morden \\ Research Station, Unit 100-101, Route 100, Morden, MB, R6M 1Y5
}

\begin{abstract}
Chen, Y.-Y., Conner, R. L., Gillard, C. L., Boland, G. J., Babcock, C., Chang, K.-F., Hwang, S. F., and Balasubramanian, P. M. 2007. A specific and sensitive method for the detection of Colletotrichum lindemuthianum in dry bean tissue. Plant Dis. 91:1271-1276.

To facilitate early diagnosis and improve control of bean anthracnose, a rapid, specific, and sensitive polymerase chain reaction (PCR)-based method was developed to detect the causal agent, Colletotrichum lindemuthianum, in bean (Phaseolus vulgaris) seed. Based on sequence data of the rDNA region consisting of the 5.8S gene and internal transcribed spacers (ITS) 1 and 2 of four $C$. lindemuthianum races and 17 Colletotrichum species downloaded from GenBank, five forward primers were designed and evaluated for their specificity. Among them, one forward primer was selected for use in combination with ITS4 to specifically detect $C$. lindemuthianum. A 461-bp specific band was amplified from the genomic DNA template of 16 representative isolates of C. lindemuthianum, but not from 58 representative isolates of 17 other Colletotrichum species or 10 bean pathogens. Moreover, to enhance the sensitivity of detection, nested PCR was applied, which allowed the detection of as little as $10 \mathrm{fg}$ of $C$. lindemuthianum genomic DNA and $1 \%$ infected seed powder, which was mixed with $99 \%$ healthy seed powder. The diagnostic analysis can be completed within $24 \mathrm{~h}$, compared with about 2 weeks required for culturing. Furthermore, this method can be performed and interpreted by personnel with no specialized taxonomic expertise.
\end{abstract}

Additional keywords: PCR-based detection

Bean anthracnose, caused by the fungus Colletotrichum lindemuthianum (Sacc. \& Magnus) Lams.-Scrib., is a serious seedborne disease of common beans (Phaseolus vulgaris L.). This pathogen is distributed worldwide and causes devastating losses in fields planted with infected seed (29), especially when climatic conditions favor disease development (12). Anthracnose has caused serious reductions in the yield of beans in many parts of the world, resulting in yield losses as high as $95 \%$ (21). Seed infection by C. lindemuthianum

Corresponding author: R. L. Conner

E-mail: conner@agr.gc.ca

* The $\boldsymbol{e}$-Xtra logo stands for "electronic extra" and indicates that an additional figure not included in the print edition is available online.

Accepted for publication 3 May 2007.

doi:10.1094/PDIS-91-10-1271

This article is in the public domain and not copyrightable. It may be freely reprinted with customary crediting of the source. The American Phytopathological Society, 2007. can also reduce seed quality and result in the introduction of the disease into new areas or new races into new geographic regions (29). Anthracnose control is complicated by the ability of $C$. lindemuthianum to survive for up to 22 months in plant debris in northern latitudes (5).

During the first 50 years or so of the last century, traditional Colletotrichum systematics relied heavily upon host-related criteria, and up to 750 species belonging to the Colletotrichum genus have been described based primarily on host specificity. Subsequently, von Arx (30) reduced the genus to 11 species with 12 forms based on morphological traits rather than the host-related criteria. Species numbers have since crept upward with more detailed studies on morphology, cultural characteristics, and pathogenicity, so that currently 38 species have been accepted (28). However, crop breeders and plant pathologist still prefer to use the original species names that are based on the host-related criteria due to their importance and specificity in causing plant diseases. The different taxonomic approaches have resulted in confusion regarding species identification within the genus Colletotrichum.

The planting of pathogen-free seed is a key recommendation for the control of bean anthracnose (25). However, this requires a highly sensitive assay system to determine whether or not seed is free of the pathogen. Current assays to detect and identify $C$. lindemuthianum in bean tissues include plating on microbial media, which is sometimes followed by the spray inoculation of seedlings with a spore suspension. Although valuable, the plating process can require up to 14 days to complete and is not completely reliable. Polymerase chain reaction (PCR)-based techniques have several potential advantages over conventional diagnostic methods in that they are more accurate, faster, and can be used by personnel with little experience in mycology or plant pathology $(1,15,20)$. By employing specific PCR primers, it is possible to selectively amplify DNA of the pathogen from infected tissues without the need for isolation of the pathogen. The specificity of PCR is derived from the selection of the synthetic oligonucleotide primers. Depending on the choice of primers, PCR can facilitate the detection of a single pathogen or many members of a group of related pathogens (15). Ultimately, PCR procedures will be available for the detection of all seedborne pathogens (32).

In fungi, there are three common DNA sequences used for diagnostic development. The first is the nuclear rDNA region, which usually consists of three genes - the large subunit gene, the small subunit gene, and the $5.8 \mathrm{~S}$ gene-separated by internal transcribed spacer (ITS) regions, which are repeated many times in a unit (20). The second is the $\beta$-tubulin gene $(10,16)$. The third is an ascomycete mating-type gene $(8,9)$. Among them, the ITS region is the most widely sequenced DNA region in fungi. It typically has been most useful for molecular systematics at the species level and even within species (e.g., to identify geographic races) (34). Some primers based on ITS sequence information have 
been designed to specifically detect related fungal pathogens $(11,13,17,23,35,37)$. In common bean, rapid, highly sensitive PCR-based detection systems have been developed for viral diseases such as Bean yellow mosaic virus (31) and bacterial diseases such as halo blight and common bacterial blight (2). For bean anthracnose, three race-specific random amplified polymorphic DNA (RAPD) markers have been developed to identify races 64,65 , and 73 from fungal DNA (22).

Touchdown PCR was developed by Don et al. (6) and used to circumvent spurious priming during DNA amplification. This method can avoid amplifying misprimed products and conveniently bypasses spurious amplifications without the need for lengthy optimization procedures. Even in cases where an appropriate discriminatory temperature has been empirically determined, the touchdown approach can also help avoid secondary problems, such as an inconsistency of well temperatures within or between thermal cyclers (6). Moreover, nested PCR has been identified as an effective technique to enhance detection sensitivity (20,36). For this procedure, two PCRs are carried out with the first reaction increasing the amount of template for the second reaction (33). In some situations, nested PCR is necessary to achieve consistently high sensitivity and reduce the incidence of false negatives (18).

Although the timely application of foliar fungicides provides an effective means for controlling $C$. lindemuthianum (4), using disease-free seed is also an effective and practical strategy for control of bean anthracnose. Detection of pathogen contamination requires a quick and effective diagnostic test assay that can be used on seed and plant samples. Currently, no research on the development of a PCR-based method for anthracnose detection in common bean has been reported. The purpose of this study was to develop a reliable, rapid, speciesspecific, sensitive molecular assay to detect C. lindemuthianum in bean tissues.

\section{MATERIALS AND METHODS}

Sources of isolates and production of mycelial mats. The original sources of all microbial isolates used in this study are listed in Table 1. Each fungal culture was revived from a stock culture and grown on potato dextrose agar (PDA) (Difco, Sparks, MD) and/or Mathur's medium (19) agar (MMA) at $21^{\circ} \mathrm{C}$. Agar plugs taken from the actively growing margins of colonies were transferred to flasks containing $50 \mathrm{ml}$ of potato dextrose broth (PDB). The flasks were incubated in shake culture at $100 \mathrm{rpm}$ at $21^{\circ} \mathrm{C}$ in the dark for 3 to 7 days. The mycelial mats were removed, dried on filter paper for immediate DNA extraction, or lyophilized with liquid nitrogen and stored at $-80^{\circ} \mathrm{C}$ for later use.

DNA extraction. Fungal genomic DNA was extracted from mycelial mats using either a modified CTAB (cetyl trimethyl ammonium bromide) procedure (7) or a DNeasy Plant Mini Kit (Qiagen, Mississauga, ON) according to the manufacturer's protocol. For the CTAB method, approximately $50 \mathrm{mg}$ of fresh, filter paperdried mycelium was transferred to a $1.5-\mathrm{ml}$ microcentrifuge tube containing $588 \mu \mathrm{l}$ of $2 \times$ CTAB buffer preheated at $65^{\circ} \mathrm{C}(2 \%$ CTAB, $100 \mathrm{mM}$ Tris-HCl, $1.4 \mathrm{M} \mathrm{NaCl}, 20$ mM EDTA, $1 \% \beta$-mercaptoethanol, $1 \%$ PVP-40, $\mathrm{pH} \mathrm{8.0)} \mathrm{and} 12 \mu \mathrm{l}$ of $10 \mathrm{mg} \mathrm{ml}^{-1}$ Proteinase K (Sigma-Aldrich, Steinheim, Germany). The mycelial tissue was ground with a plastic minipestle (Fisher Scientific, Ottawa, ON) for 3 to $5 \mathrm{~min}$ and incubated at $65^{\circ} \mathrm{C}$ in a water bath for $1 \mathrm{~h}$ with occasional gentle swirling. The mix was directly subjected to a chloroform:isoamyl alcohol (24:1) extraction step. The DNA pellet was dissolved in $100 \mu \mathrm{l}$ of $10 \mathrm{mM}$ Tris buffer, treated with RNase A (SigmaAldrich, Steinheim, Germany) $\left(10 \mu \mathrm{g} \mathrm{ml}^{-1}\right)$ at $37^{\circ} \mathrm{C}$ for $1 \mathrm{~h}$.

Total DNA from healthy and infected bean seed, and from infected plant leaves, were separately extracted using either the modified CTAB method or DNeasy Plant Mini Kit according to the manufacturer's protocol. The seeds were surface-sterilized in $70 \%$ ethanol for $30 \mathrm{~s}$ and washed three times with sterilized distilled water prior to DNA isolation. For the bacterial pathogens of common bean, total genomic DNA was extracted from cultures growing on PDA plates with a DNeasy Plant Mini Kit. The concentration of DNA stocks was estimated using a DU 640B spectrophotometer (Beckman, Fullerton, CA) set at 260 nm. DNA quality was evaluated according to the value of $A_{260 \mathrm{~nm}} / A_{280 \mathrm{~nm}}(24)$.

Primer design for $C$. lindemuthianum. Twenty-one DNA referential ITS sequences of four $C$. lindemuthianum races and 17 other Colletotrichum species were downloaded from GenBank through the National Center for Biotechnology Information (NCBI), National Library of Medicine, National Institutes of Health website, and edited and aligned with BioEdit version 7.0 software (14). Only one species-specific single nucleotide polymorphism (SNP) site located in the ITS1 region distinguished $C$. lindemuthianum from other Colletotrichum species. The sequence diversity of the $5.8 \mathrm{~S}$ and ITS2 was too small to design any species-specific reverse primers. Therefore, based on the relative higher diversity in the ITS1 region among sequences of four C. lindemuthianum and 17 other Colletotrichum species, five forward primers, ClF1, ClF2, ClF3, ClF4, and ClF5, were manually designed for $C$. lindemuthianum. The possibility of hairpin formation and other primer parameters were evaluated with Primer Premier 5.0 software (26). The above primers were synthesized (Invitrogen Corp., Carlsbad, CA).
PCR amplification. The target band was amplified with a touchdown PCR program (6). Reaction volumes were $25 \mu \mathrm{l}$ and consisted of $1 \times$ PCR buffer, $1.5 \mathrm{mM}$ $\mathrm{MgCl}_{2}, 125 \mu \mathrm{M}$ each of dNTP, $250 \mathrm{nM}$ of each forward and reverse primer, 0.5 units of AmpliTaq DNA polymerase (ABI, Foster City, CA), and 25 to $60 \mathrm{ng}$ of sample DNA. PCR was performed in a PTC-100 thermocycler (MJ Research Inc., Watertown, MA). The PCR program was optimized and consisted of initial denaturation at $95^{\circ} \mathrm{C}$ for $5 \mathrm{~min}, 12$ cycles of $30 \mathrm{~s}$ at $94^{\circ} \mathrm{C}, 30 \mathrm{~s}$ from $62^{\circ} \mathrm{C}$ to a "touchdown" (the annealing temperature was lowered $1^{\circ} \mathrm{C}$ in each subsequent cycle) at $50^{\circ} \mathrm{C}$ for primer annealing, $1 \mathrm{~min}$ at $72^{\circ} \mathrm{C}$ for primer extension, followed by 30 cycles with a $50^{\circ} \mathrm{C}$ annealing temperature, and ended with 1 cycle of $5 \mathrm{~min}$ at $72^{\circ} \mathrm{C}$.

For nested PCR, the universal primer set ITS5/ITS4 (34) was used as the outer primers in the first round of PCR, $1-\mu l$ aliquot of 10 times diluted first-round PCR product was used as the template in the second PCR using the selected forward primer ClF4 and ITS4 with the same touchdown PCR program. The PCR products were separated on a $1.4 \%$ agarose gel in $1 \times$ TBE buffer at $100 \mathrm{~V}$ for $1 \mathrm{~h}$. The gels were stained with ethidium bromide and visualized under UV light using an AlphaImager gel documentation system (Alpha Innotech, San Leandro, CA).

Test of primer specificity. Combined with the reverse primer ITS4, five forward primers $\mathrm{ClF} 1$ to $\mathrm{ClF} 5$ were separately tested for species-specificity to $C$. lindemuthianum using genomic DNA of seven C. lindemuthianum races and 16 representatives of other Colletotrichum species. The selected species-specific primer set was evaluated further with DNA from an additional 29 Colletotrichum isolates, 18 isolates of other bean pathogens, and the anthracnose-resistant bean differential line, G2333 (Table 1).

Detection of $C$. lindemuthianum in bean seed and plant leaves. The selected primer set $\mathrm{ClF} 4$ and ITS4 was used to detect $C$. lindemuthianum from bean seed and infected plant leaves using nested PCR. Seeds of the pinto bean cultivar AC Pintoba were used. Sixteen seeds with typical symptoms and 19 seeds with a healthy appearance were surface-sterilized in $70 \%$ ethanol for $30 \mathrm{~s}$ and washed three times in sterilized distilled water. The seeds were dried on sterilized filter paper, and batches of healthy and diseased seed were separately ground into a fine powder using a new coffee grinder (Proctor-Silex, Hamilton, CA) for later DNA extraction. Different percentages of the $C$. lindemuthianum-infected seed powder were serially mixed with healthy seed powder to test the minimum level of detection using the species-specific primer set. A total of $0.1 \mathrm{~g}$ of ground seed powder was used for each sample. The infected and healthy seed 
Table 1. Species, isolates, host, and origin of fungal and bacterial isolates and plant samples used, and results of the polymerase chain reaction (PCR) amplification using the ClF4 and ITS4 primer set

\begin{tabular}{|c|c|c|c|c|c|}
\hline Code & Species & Isolates & Host & Origin & $\begin{array}{c}\text { PCR } \\
\text { product }^{\mathrm{a}}\end{array}$ \\
\hline 1 & Colletotrichum lindemuthianum & Race 2 & Phaseolus vulgaris & Mich. St. Univ. & + \\
\hline 2 & Colletotrichum lindemuthianum & Race 17 & Phaseolus vulgaris & AAFC-Harrow & + \\
\hline 3 & Colletotrichum lindemuthianum & Race 23 & Phaseolus vulgaris & AAFC-Harrow & + \\
\hline 4 & Colletotrichum lindemuthianum & Race 31 & Phaseolus vulgaris & AAFC-Harrow & + \\
\hline 5 & Colletotrichum lindemuthianum & Race 73 & Phaseolus vulgaris & AAFC-Morden & + \\
\hline 6 & Colletotrichum lindemuthianum & Race 89 & Phaseolus vulgaris & AAFC-Harrow & + \\
\hline 7 & Colletotrichum lindemuthianum & Race 1096 & Phaseolus vulgaris & AAFC-Morden & + \\
\hline 8 & Colletotrichum lindemuthianum & DAOM 225470 & Phaseolus vulgaris & $\mathrm{CCFC}^{\mathrm{b}}$ & + \\
\hline 9 & Colletotrichum lindemuthianum & DAOM 225471 & Phaseolus vulgaris & CCFC & + \\
\hline 10 & Colletotrichum lindemuthianum & DAOM 225472 & Phaseolus vulgaris & CCFC & + \\
\hline 11 & Colletotrichum lindemuthianum & DAOM 225473 & Phaseolus vulgaris & $\mathrm{CCFC}$ & + \\
\hline 12 & Colletotrichum lindemuthianum & DAOM 225581 & Phaseolus vulgaris & $\mathrm{CCFC}$ & + \\
\hline 13 & Colletotrichum lindemuthianum & DAOM 225739 & Phaseolus vulgaris & CCFC & + \\
\hline 14 & Colletotrichum lindemuthianum & DAOM 225740 & Phaseolus vulgaris & CCFC & + \\
\hline 15 & Colletotrichum lindemuthianum & DAOM 225741 & Phaseolus vulgaris & CCFC & + \\
\hline 16 & Colletotrichum lindemuthianum & DAOM 225742 & Phaseolus vulgaris & $\mathrm{CCFC}$ & + \\
\hline 17 & Colletotrichum acutatum & DAOM 185681 & Unknown & CCFC & - \\
\hline 18 & Colletotrichum acutatum & DAOM 212360A & Unknown & CCFC & - \\
\hline 19 & Colletotrichum acutatum & DAOM 214715 & Unknown & CCFC & - \\
\hline 20 & Colletotrichum acutatum & DAOM 214992 & Unknown & $\mathrm{CCFC}$ & - \\
\hline 21 & Colletotrichum acutatum & DAOM 215166 & Unknown & $\mathrm{CCFC}$ & - \\
\hline 22 & Colletotrichum brassicae & DAOM 116226 & Unknown & CCFC & - \\
\hline 23 & Colletotrichum capsici & DAOM 212661 & Unknown & CCFC & - \\
\hline 24 & Colletotrichum circinans & DAOM 151616 & Unknown & $\mathrm{CCFC}$ & - \\
\hline 25 & Colletotrichum coccodes & DAOM 60413 & Unknown & $\mathrm{CCFC}$ & - \\
\hline 26 & Colletotrichum coccodes & DAOM 145740 & Unknown & $\mathrm{CCFC}$ & - \\
\hline 27 & Colletotrichum coccodes & DAOM 182572 & Unknown & $\mathrm{CCFC}$ & - \\
\hline 28 & Colletotrichum coccodes & DAOM 214592 & Unknown & $\mathrm{CCFC}$ & - \\
\hline 29 & Colletotrichum coccodes & DAOM 216029 & Unknown & $\mathrm{CCFC}$ & - \\
\hline 30 & Colletotrichum dematium & DAOM 96293 & Unknown & $\mathrm{CCFC}$ & - \\
\hline 31 & Colletotrichum dematium & DAOM 147549 & Unknown & $\mathrm{CCFC}$ & - \\
\hline 32 & Colletotrichum dematium & DAOM 188792 & Unknown & $\mathrm{CCFC}$ & - \\
\hline 33 & Colletotrichum dematium & DAOM 212662 & Unknown & $\mathrm{CCFC}$ & - \\
\hline 34 & Colletotrichum destructivum & DAOM 179749 & Unknown & $\mathrm{CCFC}$ & - \\
\hline 35 & Colletotrichum destructivum & DAOM 196849 & Unknown & $\mathrm{CCFC}$ & - \\
\hline 36 & Colletotrichum destructivum & DAOM 216020 & Unknown & $\mathrm{CCFC}$ & - \\
\hline 37 & Colletotrichum destructivum & DAOM 225584 & Unknown & $\mathrm{CCFC}$ & - \\
\hline 38 & Colletotrichum fuscum & DAOM 216112 & Unknown & $\mathrm{CCFC}$ & - \\
\hline 39 & Colletotrichum gloeosporioides & DAOM 183087 & Unknown & $\mathrm{CCFC}$ & - \\
\hline 40 & Colletotrichum gloeosporioides & DAOM 214710 & Unknown & $\mathrm{CCFC}$ & - \\
\hline 41 & Colletotrichum gloeosporioides & DAOM 225300 & Unknown & $\mathrm{CCFC}$ & - \\
\hline 42 & Colletotrichum graminicola & DAOM 231462 & Unknown & $\mathrm{CCFC}$ & - \\
\hline 43 & Colletotrichum graminicola & DAOM 232153 & Unknown & $\mathrm{CCFC}$ & - \\
\hline 44 & Colletotrichum higginsianum & DAOM 225478 & Unknown & $\mathrm{CCFC}$ & - \\
\hline 45 & Colletotrichum lini & DAOM 183091 & Unknown & $\mathrm{CCFC}$ & - \\
\hline 46 & Colletotrichum mиsae & DAOM 182828 & Unknown & $\mathrm{CCFC}$ & - \\
\hline 47 & Colletotrichum pisi & DAOM 196850 & Unknown & $\mathrm{CCFC}$ & - \\
\hline 48 & Colletotrichum subliniolum & DAOM 212374 & Unknown & $\mathrm{CCFC}$ & - \\
\hline 49 & Colletotrichum truncatum & DAOM 215174 & Unknown & CCFC & - \\
\hline 50 & Colletotrichum truncatum & DAOM 233303 & Unknown & CCFC & - \\
\hline 51 & Colletotrichum truncatum & DAOM 233308 & Unknown & $\mathrm{CCFC}$ & - \\
\hline 52 & Colletotrichum truncatum & DAOM 233314 & Unknown & $\mathrm{CCFC}$ & - \\
\hline 53 & Uromyces phaseoli & Mb05-70 & Phaseolus vulgaris & AAFC-Morden & - \\
\hline 54 & Sclerotinia sclerotiorum & $\ldots$ & Phaseolus vulgaris & AAFC-Morden & - \\
\hline 55 & Fusarium solani f. sp. phaseoli & $\ldots$ & Phaseolus vulgaris & AAFC-Morden & - \\
\hline 56 & Fusarium solani f. sp. pisi & 98Fus016-1 & Pisum sativum & AAFC-Morden & - \\
\hline 57 & Rhizoctonia solani & $\ldots$ & Phaseolus vulgaris & AAFC-Morden & - \\
\hline 58 & Pythium spp. & P-p3 & Pisum sativum & AAFRD-Lacombe & - \\
\hline 59 & Pythium spp. & P-p9 & Pisum sativum & AAFRD-Lacombe & - \\
\hline 60 & Pythium spp. & P-p31 & Pisum sativum & AAFRD-Lacombe & - \\
\hline 61 & Pythium spp. & P-P88-P3 & Pisum sativum & AAFRD-Lacombe & - \\
\hline 62 & Botrytis cinerea & B-3 & Lupinus angustifolius & Devon & - \\
\hline 63 & Botrytis cinerea & B-12 & Lupinus angustifolius & Devon & - \\
\hline 64 & Botrytis cinerea & B-89 & Lupinus angustifolius & Ellerslie & - \\
\hline 65 & Botrytis cinerea & B-16 & Lupinus angustifolius & Penhold & - \\
\hline 66 & Botrytis cinerea & B-4c & Lupinus angustifolius & Barrhead & - \\
\hline 67 & Xanthomonas campestris pv. phaseoli & BXP-2 & Phaseolus vulgaris & AAFC-Morden & - \\
\hline 68 & Pseudomonas syringae pv. phaseolicola & HB06-2 & Phaseolus vulgaris & AAFC-Morden & - \\
\hline 69 & Corynebacterium flaccumfaciens & OSB-3 & Phaseolus vulgaris & AAFC-Lethbridge & - \\
\hline 70 & Phaeoisariopsis griseola & MYA-2353 & Phaseolus vulgaris & Univ. of Guelph & - \\
\hline 71 & Phaseolus vulgaris (G2333) & $\ldots$ & $\ldots$ & AAFC-Morden & - \\
\hline 72 & DNA grade water & $\ldots$ & $\ldots$ & $\ldots$ & - \\
\hline
\end{tabular}

${ }^{\mathrm{a}}+=$ PCR product was observed after electrophoresis, and $-=$ no PCR product was observed after electrophoresis.

${ }^{\mathrm{b}}$ Canadian Collection of Fungal Cultures. 
powder were mixed sequentially starting with the lowest dilution. The rates of infected seed powder included 100, 80, 60, 40, 20, 10, 8, 6, 4, 2, 1, and $0 \%$ (wt/wt). Additionally, genomic DNA extracted from the seeds of the resistant differential line, G2333, and the reaction mixture without DNA were used as negative controls. DNA from a pure culture of C. lindemuthianum race 73 was used as the positive control. Total DNA from infected leaves was used to detect $C$. lindemuthianum employing the same PCR procedure.

Moreover, a 10-fold dilution series of $C$. lindemuthianum genomic DNA was used to test the minimum amount of DNA template required for producing a detectable target band with the primer set $\mathrm{ClF} 4$ and ITS4 directly by nested PCR.

\section{RESULTS}

Sequence analysis of the ITS region of Colletotrichum species and primer design. ITS fragments were sequenced from seven identified $C$. lindemuthianum races in this study, and four other C. lindemuthianum ITS sequences were downloaded from the GenBank. The ITS sequences of six races (race 17, 23, 31, 73, 89, and 1096) and isolate MAFF 305390 (GenBank accession no. AB087222) were identical. The sequences of the ITS region of race 2, strain BBA 65483 (GenBank accession no. AJ301958), strain CBS 151.28 (GenBank accession no. AJ301946), and strain CBS 132.57 (GenBank accession no. AJ301947) also were identical. There were only three base substitutions between these two ITS sequences. In an aligned ITS se- quence matrix consisting of four $C$. lindemuthianum strains and 17 other Colletotrichum species, sequence identity ranged from 86.9 to $99.2 \%$. Based on sequence differences in a 21 -sequence data matrix, five forward primers, ClF1, ClF2, ClF3, $\mathrm{ClF} 4$, and $\mathrm{ClF} 5$, were designed and tested for their specificity in detecting $C$. lindemuthianum (Table 2).

Specific amplification of $C$. lindemuthianum. With genomic DNA extracted from pure microbial cultures, the touchdown PCR program was used to select a species-specific primer set among the five designed forward primers $\mathrm{ClF} 1, \mathrm{ClF} 2$, ClF3, ClF4, and ClF5. Seven identified $C$. lindemuthianum races (races 2, 17, 23, 31, 73,89 , and 1096) and 16 representatives of other Colletotrichum species were tested to determine the species-specificity of the five primer sets. All primer sets could direct successful amplification from the seven C. lindemuthianum races. However, $\mathrm{ClF} 1, \mathrm{ClF} 2, \mathrm{ClF} 3$, and ClF5 forward primers, combined with ITS4, also produced target fragments from some of the other Colletotrichum species. The primer pair CIF4/ITS4 produced a 461-bp amplified fragment from the seven $C$. lindemuthianum races, and none from the other 16 Colletotrichum species (Table 2). A total of 74 genomic DNA samples derived from different microbial isolates were used to evaluate specificity of PCR amplification with primer set ClF4/ITS4 (Table 1). These microbial isolates included the other 16 Colletotrichum species, causal pathogens of seven fungal diseases and three bacterial diseases of common bean. The primer set ClF4/ITS4 directed a 461-bp DNA frag- ment amplification from only the 16 identified $C$. lindemuthianum isolates, but not from the other Colletotrichum species or bean pathogens. Therefore, this primer pair was further used to detect C. lindemuthianum in infected bean tissues.

Evaluation of detection sensitivity. A 10-fold dilution series of $C$. lindemuthianum race 2 genomic DNA was used to evaluate the detection sensitivity of the selected primer set ClF4 and ITS4. The primer set could direct visible amplified fragments from as little as $10 \mathrm{pg}$ of DNA using single-step PCR (Y. Chen, unpublished data). In nested PCR, the universal primer set ITS5/ITS4 was used in the firstround and the ClF4/ITS4 primer set was used in the second-round PCR reaction. One microliter of 10-times diluted firstround PCR products was used as template for the second-round PCR, and as little as $10 \mathrm{fg}$ of $C$. lindemuthianum genomic DNA could be detected (Fig. 1). The nested PCR was approximately 1,000 times more sensitive than the single-step PCR assay.

Using single-step PCR, the PCR results were unstable and the sensitivity was low for genomic DNA from infected leaves and different mixtures of infected and healthy bean seed powder (Y. Chen, unpublished data). Therefore, the nested PCR method was employed to directly detect $C$. lindemuthianum in infected bean tissues. A 461bp DNA fragment was produced from genomic DNA of individual infected leaves with nested PCR (Fig. 2). Visible PCR products in ethidium bromide-stained gels after electrophoresis could be produced from the template DNA extracted from mixed seed samples, which included 100

Table 2. Species, isolates, host, origin of fungal isolates used, and results of the polymerase chain reaction (PCR) amplification using ClF1 to ClF5 and ITS4 primer sets

\begin{tabular}{|c|c|c|c|c|c|c|c|c|c|}
\hline \multirow[b]{2}{*}{ Code } & \multirow[b]{2}{*}{ Species } & \multirow[b]{2}{*}{ Isolates } & \multirow[b]{2}{*}{ Host } & \multirow[b]{2}{*}{ Origin } & \multicolumn{5}{|c|}{ PCR product ${ }^{\mathbf{a}}$} \\
\hline & & & & & CIF1 & CIF2 & CIF3 & CIF4 & ClF5 \\
\hline 1 & Colletotrichum lindemuthianum & Race 2 & Phaseolus vulgaris & Mich. St. Univ. & + & + & + & + & + \\
\hline 2 & Colletotrichum lindemuthianum & Race 17 & Phaseolus vulgaris & AAFC-Harrow & + & + & + & + & + \\
\hline 3 & Colletotrichum lindemuthianum & Race 23 & Phaseolus vulgaris & AAFC-Harrow & + & + & + & + & + \\
\hline 4 & Colletotrichum lindemuthianum & Race 31 & Phaseolus vulgaris & AAFC-Harrow & + & + & + & + & + \\
\hline 5 & Colletotrichum lindemuthianum & Race 73 & Phaseolus vulgaris & AAFC-Morden & + & + & + & + & + \\
\hline 6 & Colletotrichum lindemuthianum & Race 89 & Phaseolus vulgaris & AAFC-Harrow & + & + & + & + & + \\
\hline 7 & Colletotrichum lindemuthianum & Race 1096 & Phaseolus vulgaris & AAFC-Morden & + & + & + & + & + \\
\hline 8 & Colletotrichum acutatum & DAOM 214715 & Unknown & $\mathrm{CCFC}$ & + & + & - & - & + \\
\hline 9 & Colletotrichum brassicae & DAOM 116226 & Unknown & $\mathrm{CCFC}$ & + & + & - & - & + \\
\hline 10 & Colletotrichum capsici & DAOM 212661 & Unknown & $\mathrm{CCFC}$ & - & + & + & - & + \\
\hline 11 & Colletotrichum circinans & DAOM 151616 & Unknown & $\mathrm{CCFC}$ & + & - & + & - & + \\
\hline 12 & Colletotrichum coccodes & DAOM 60413 & Unknown & $\mathrm{CCFC}$ & + & + & + & - & + \\
\hline 13 & Colletotrichum dematium & DAOM 188792 & Unknown & $\mathrm{CCFC}$ & + & + & - & - & + \\
\hline 14 & Colletotrichum destructivum & DAOM 179749 & Unknown & $\mathrm{CCFC}$ & + & + & + & - & + \\
\hline 15 & Colletotrichum fuscum & DAOM 216112 & Unknown & $\mathrm{CCFC}$ & - & + & - & - & + \\
\hline 16 & Colletotrichum gloeosporioides & DAOM 183087 & Unknown & $\mathrm{CCFC}$ & - & + & + & - & + \\
\hline 17 & Colletotrichum graminicola & DAOM 231462 & Unknown & $\mathrm{CCFC}$ & + & + & + & - & + \\
\hline 18 & Colletotrichum higginsianum & DAOM 225478 & Unknown & $\mathrm{CCFC}$ & + & + & + & - & + \\
\hline 19 & Colletotrichum lini & DAOM 183091 & Unknown & $\mathrm{CCFC}$ & + & - & - & - & + \\
\hline 20 & Colletotrichum musae & DAOM 182828 & Unknown & $\mathrm{CCFC}$ & + & - & - & - & + \\
\hline 21 & Colletotrichum pisi & DAOM 196850 & Unknown & $\mathrm{CCFC}$ & - & - & - & - & + \\
\hline 22 & Colletotrichum subliniolum & DAOM 212374 & Unknown & $\mathrm{CCFC}$ & + & + & + & - & + \\
\hline 23 & Colletotrichum truncatum & DAOM 215174 & Unknown & $\mathrm{CCFC}$ & + & + & - & - & + \\
\hline
\end{tabular}

a Primers designed for PCR were ClF1 (5'-CCCTTTGTGAACATACCAAACCG-3'); ClF2 (5'-TGTGAACATACCAAACCGTTGC-3'); ClF3 (5'TCCCCCCTGCCCCGCTCGCG-3'); ClF4 (5'-TCCCCCCTGCCCCGCTCG-3'); and ClF5 (5'-CGCCGGAGGAAAACCCAAC-3'). + = PCR product was observed after electrophoresis, and $-=$ no PCR product was observed after electrophoresis. 
to $1 \%$ infected seed powder (Fig. 3). The negative controls did not produce any amplicons, whereas the positive control showed a strong DNA band of the expected size.

\section{DISCUSSION}

In this study, a PCR-based assay was developed to specifically detect $C$. lindemuthianum from pure fungal DNA and mixed DNA from infected bean tissues such as seeds and leaves. The forward primer $\mathrm{ClF} 4$ was selected to be combined with the universal reverse primer ITS4 to detect $C$. lindemuthianum DNA from pure fungal DNA and fungal-plant background mixed DNA. The ITS region has proven to be useful for molecular systematics at the species level and within species. Sreenivasaprasad et al. (27) reported that in Colletotrichum species the ITS1 region has a greater degree of intra- and inter-specific divergency $(50.3 \%$ variable sites) compared with the ITS2 region (12.4\% variable sites). The maximum intraspecific divergence was recorded with $C$. acutatum $(5.8 \%)$. Colletotrichum capsici showed the greatest level of interspecific divergence (8.9 to $23.3 \%$ ). Genetic distances calculated from the ITS sequence ranged from 0.2 to $1.8 \%$ among 14 isolates of $C$. lindemuthianum that were collected in North, Central, and South America and the Netherlands (3). However, C. lindemuthianum is a species primarily based on a hostpathogen criterion, not a real phylogenetic species $(28,30)$. In this study, the average ITS sequence divergence between $C$. lindemuthianum and other Colletotrichum species was $11.5 \%$, and no species-specific sequence information could be found in the 5.8S and ITS2 regions of the $C$. lindemuthianum sequence. It was difficult to find an opportunity to design possible specific reverse primers in the $5.8 \mathrm{~S}$ or ITS2 region. Similarly, using the specific forward primer $\mathrm{CgInt}$ and the universal reverse primer ITS4, a PCR-based assay had been developed to detect C. gloeosporioides Penz. from infected tomato fruits (23).

The annealing temperature of the touchdown PCR used in this study was decreased $1{ }^{\circ} \mathrm{C}$ per cycle from $62^{\circ} \mathrm{C}$ to a touchdown temperature of $50^{\circ} \mathrm{C}$. Any imbalance between correct and spurious annealing was automatically redressed, which eliminated the time required to determine the best annealing temperature for every primer set during the PCR program optimization procedure. In this study, five designed primers with different Tm (melting temperature) values directed successful amplification with the same touchdown PCR program. Touchdown PCR has several advantages in comparison to a PCR program with fixed annealing temperature, since it can be applied in several situations, such as running in different thermal cyclers, with different PCR kits or different operators. For plant pathogen detection, touchdown PCR can permit PCR-based testing of several plant pathogens in one thermal cycler simultaneously. Furthermore, it has the potential to allow the use of different primer sets in PCR detection for several related plant pathogens in one tube.

Apart from specificity, the sensitivity of detection also is important for early disease diagnosis. The sensitivity of a PCR assay depends on several factors, including the quality of the prepared genomic DNA, primer composition, structure and homology of the target molecule, concentration of magnesium, other components of the PCR reaction buffer, and the PCR program. In this study, nested PCR was employed to improve the detection sensitivity of the pathogen in the host tissues. The first-round PCR with universal primer set ITS5/ITS4 enriched the ITS fragments both from plant and fungal genomic DNA. A designed specific forward primer com-

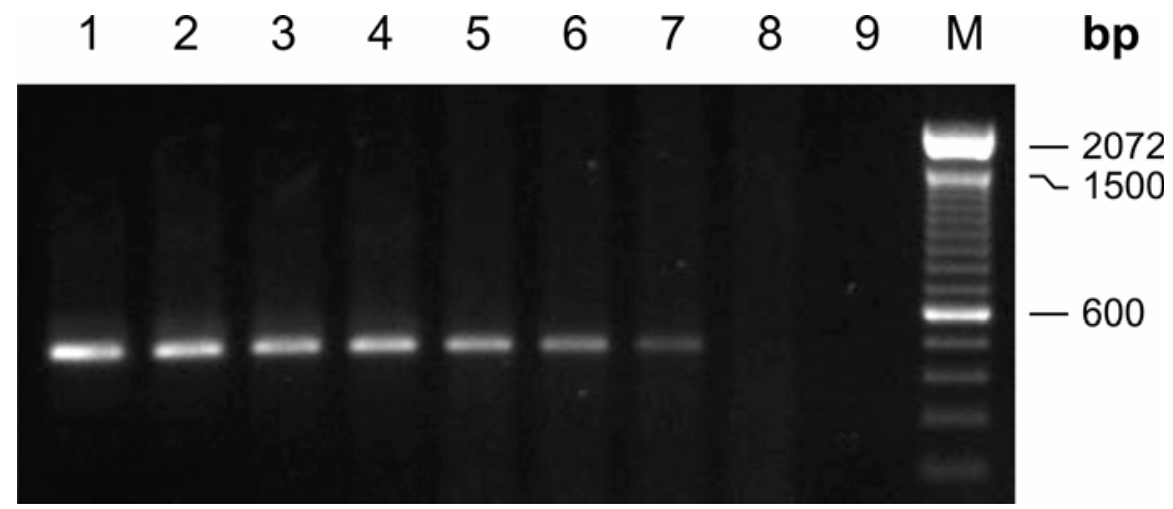

Fig. 1. Evaluation of detection sensitivity using nested polymerase chain reaction (PCR) with fungal genomic DNA extracted from a pure Colletotrichum lindemuthianum culture in a 10-fold dilution series. Lanes: $\mathrm{M}=100$-bp DNA ladder (Invitrogen), $1=10 \mathrm{ng} \mu \mathrm{l}^{-1}, 2=1 \mathrm{ng}^{-1} \mathrm{l}^{-1}, 3=100 \mathrm{pg}^{\mathrm{l}} \mathrm{l}^{-1}, 4=$

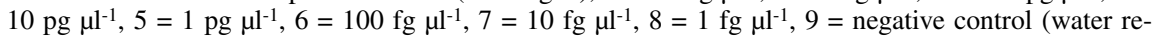
placed genomic DNA as the template).

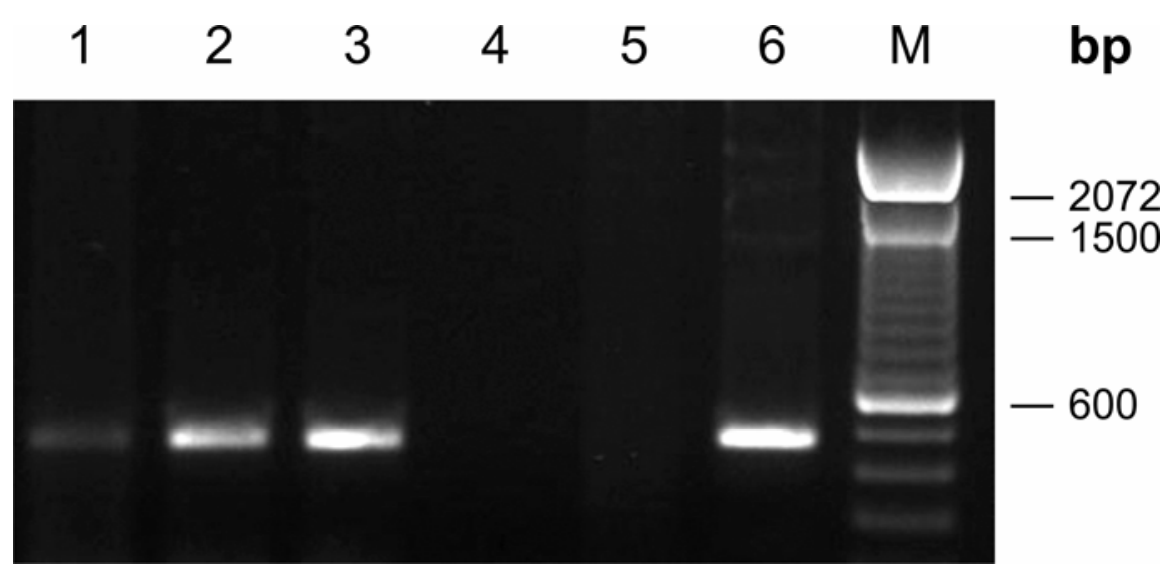

Fig. 2. Detection of Colletotrichum lindemuthianum from infected bean leaves using nested polymerase chain reaction (PCR). Lanes: $\mathrm{M}=100$-bp DNA ladder (Invitrogen), 1 to $3=C$. lindemuthianum infected leaves, $4=$ anthracnose-resistant bean genotype G2333, 5 = negative control (water replaced genomic DNA as the template), $6=$ positive control (C. lindemuthianum DNA).

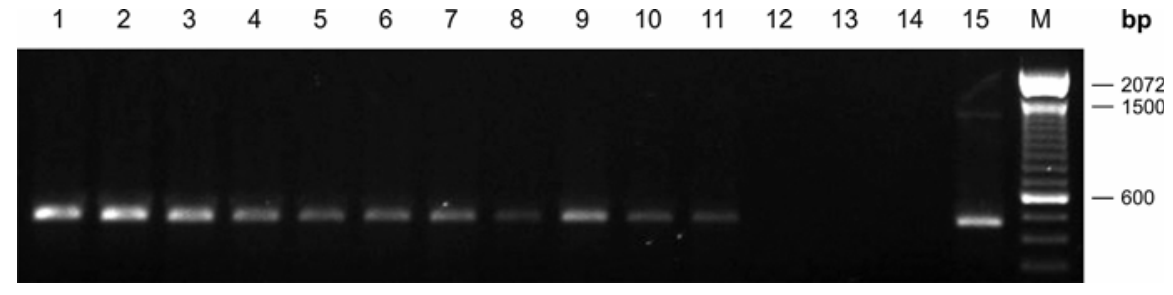

Fig. 3. Amplification of Colletotrichum lindemuthianum DNA from mixed infected and healthy bean seeds powder at different concentrations using nested polymerase chain reaction (PCR). Lanes: $\mathrm{M}=$ 100-bp DNA ladder (Invitrogen), $1=100 \%, 2=80 \%, 3=60 \%, 4=40 \%, 5=20 \%, 6=10 \%, 7=8 \%$, $8=6 \%, 9=4 \%, 10=2 \%, 11=1 \%, 12=0 \%, 13=$ anthracnose-resistant bean genotype G2333, $14=$ negative control (water replaced genomic DNA as the template), $15=$ positive control $(C$. lindemuthianum DNA). 
bined with universal reverse primer was then used to selectively amplify the target pathogen DNA. As little as $10 \mathrm{fg}$ of $C$. lindemuthianum DNA was detected by nested PCR in this study, approximately the equivalent to a single fungal genome (36). Thus, the nested PCR system satisfies both the specificity and sensitivity requirements for diagnostic applications.

The PCR assay system developed in the current study should assist the dry bean seed industry in the production and distribution of anthracnose-free seed. In the past, some difficulties have been experienced with identification of infected bean plants based on symptomology. The use of this new PCR-based assay system will improve anthracnose detection and will reduce unnecessary fungicide application. This improvement in the speed of detection of the anthracnose fungus will promote more timely application of control measures when they are required.

\section{ACKNOWLEDGMENTS}

We thank the Agricultural Adaptation Council, the Manitoba Pulse Growers Association, the Ontario White Bean Producers, Ontario Coloured Bean Growers, Syngenta Crop Protection, and BASF Canada for their financial support of this project. We also thank W. C. Penner, D. B. Stoesz, and G. Penner for their technical assistance on this study. We are very grateful to S. J. Park of AAFC Harrow and J. D. Kelly of Michigan State University for providing some of the isolates of $C$. lindemuthianum.

\section{LITERATURE CITED}

1. Annamalai, P., Ishii, H., Lalithakumari, D., and Revathi, R. 1995. Polymerase chain reaction and its application in fungal disease diagnosis. Z. Pflanzenkr. Pflanzenschutz 102:91-104.

2. Audy, P., Braat, C. E., Saindon, G., Huang, H. C., and Laroche, A. 1996. A rapid and sensitive PCR-based assay for concurrent detection of bacteria causing common and halo blight in bean seed. Phytopathology 86:361-366.

3. Balardin, R. S., Smith, J. J., and Kelly, J. D. 1999. Ribosomal DNA polymorphism in Colletotrichum lindemuthianum. Mycol. Res. 103:841-848.

4. Conner, R. L., McAndrew, D. W., Kiehn, F. A., Chapman, S. R., and Froese, N. T. 2004. Effect of foliar fungicide application timing on the control of bean anthracnose in the navy bean 'Navigator'. Can. J. Plant Pathol. 26:299-303.

5. Dillard, H. R., and Cobb, A. C. 1993. Survival of Colletotrichum lindemuthianum in bean debris in New York State. Plant Dis. 77:12331238.

6. Don, R. H., Cox, P. T., Wainwright, B. J., Baker, K., and Mattick, J. S. 1991. 'Touchdown' PCR to circumvent spurious priming during gene amplification. Nucleic Acids Res. 19:4008.

7. Doyle, J. J., and Doyle, J. L. 1987. A rapid
DNA isolation procedure for small quantities of fresh leaf material. Phytochem. Bull. 19:1115 .

8. Dyer, P. S., Furneaux, P. A., Douhan, G., and Murray, T. D. 2001. A multiplex PCR test for determination of mating type applied to the plant pathogens Tapesia yallundae and Tapesia acuformis. Fung. Genet. Biol. 33:173-180.

9. Foster, S. J., Ashby, A. M., and Fitt, B. D. L. 2002. Improved PCR-based assays for presymptomatic diagnosis of light leaf spot and determination of mating type of Pyrenopeziza brassicae on winter oilseed rape. Eur. J. Plant Pathol. 108:374-383.

10. Fraaije, B., Lovell, D. J., Rohel, E. A., and Hollomon, D. W. 1999. Rapid detection and diagnosis of Septoria tritici epidemics in wheat using a polymerase chain reaction/Pico green assay. J. Appl. Microbiol. 86:701-708.

11. Frederick, R. D., Snyder, C. L., Peterson, G. L., and Bonde, M. R. 2002. Polymerase chain reaction assays for the detection and discrimination of the soybean rust pathogens Phakopsora pachyrhizi and P. meibomiae. Phytopathology 92:217-227.

12. Gonzalez, M., Rodriguez, R., Zavala, M. E., Jacobo, J. L., Hernandez, F., Acosta, J., Martinez, O., and Simpson, J. 1998. Characterization of Mexican isolates of Colletotrichum lindemuthianum by using differential cultivars and molecular markers. Phytopathology 88:292-299.

13. Goodwin, P. H., Hsiang, T., Xue, B. G., and Liu, H. W. 1995. Differentiation of Gaeumannomyces graminis from other turf-grass fungi by amplification with primers from ribosomal internal transcribed spacers. Plant Pathol. 44:384-391.

14. Hall, T. A. 1999. BioEdit: A user-friendly biological sequence alignment editor and analysis program for Windows 95/98/NT. Nucleic Acids Sympos. Ser. 41:95-98.

15. Henson, J. M., and French, R. 1993. The polymerase chain reaction and plant disease diagnosis. Annu. Rev. Phytopathol. 31:81-109.

16. Hirsch, P. R., Manchline, T. H., Mendum, T. A., and Kerry, B. R. 2000. Detection of the nematophagous fungus Verticillium chlamydosporium in nematode-infested plant roots using PCR. Mycol. Res. 104:435-439.

17. Lee, H. K., Tewari, J. P., and Turkington, T. K. 2001. A PCR-based assay to detect Rhynchosporium secalis in barley seed. Plant Dis. 85:220-225.

18. Martin, R. R., James, D., and Levesque, C. A. 2000. Impacts of molecular technologies on plant disease management. Annu. Rev. Phytopathol. 38:207-239.

19. Mathur, R. S., Barnett, H. L., and Lilly, V. G. 1950. Sporulation of Colletotrichum lindemuthianum in culture. Phytopathology 40:104114.

20. McCartney, H. A., Foster, S. J., Fraaije, B. A., and Ward, E. 2003. Molecular diagnostics for fungal plant pathogens. Pest Manag. Sci. 59:129-142.

21. Melotto, M., Balardin, R. S., and Kelly, J. D. 2000. Host-pathogen interactions and variability of Colletotrichum lindemuthianum. Pages 346-361 in: Colletotrichum: Host Specificity, Pathology, and Host-Pathogen Interaction. D. Prusky, S. Freeman, and M. B.
Dickman, eds. American Phytopathological Society, St. Paul, MN.

22. Mesquita, A. G. G., Paula, T. J., Jr., Moreira, M. A., and de Barros, E. G. 1998. Identification of races of Colletotrichum lindemuthianum with the aid of PCR-based molecular markers. Plant Dis. 82:1084-1087.

23. Mills, P. R., Sreenivasaprasad, S., and Brown, A. E. 1992. Detection and differentiation of Colletotrichum gloeosporioides isolates using PCR. FEMS Microbiol. Lett. 98:137-144.

24. Sambrook, J., Fritsch, E. F., and Maniatis, T. 1989. Molecular Cloning: A Laboratory Manual. 2nd ed. Cold Spring Harbor Laboratory, Cold Spring Harbor, NY.

25. Schwartz, H. F., Steadman, J. R., Hall, R., and Forster, R. L. 2005. Compendium of Bean Diseases. 2nd ed. American Phytopathological Society, St. Paul, MN. p. 109.

26. Singh, V. K., Mangalam, A. K., Dwivedi, S. and Naik, S. 1998. Primer premier: Program for design of degenerate primers from a protein sequence. Biotechniques 24:318-319.

27. Sreenivasaprasad, S., Mills, P. R., Meehan, B. M., and Brown, A. E. 1996. Phylogeny and systematics of 18 Colletotrichum species based on ribosomal DNA spacer sequences. Genome 39:499-512.

28. Sutton, B. C. 1992. The genus Glomerella and its anamorph Colletotrichum. Pages 1-26 in: Colletotrichum: Biology, Pathology and Control. J. A. Bailey and M. J. Jeger, eds. CAB International, Wallingford, UK.

29. Tu, J. C. 1992. Colletotrichum lindemuthianum on bean. Population dynamics of the pathogen and breeding for resistance. Pages 203-224 in: Colletotrichum: Biology, Pathology and Control. J. A. Bailey and M. J. Jeger, eds. CAB International, Wallingford, UK.

30. von Arx, J. A. 1957. Die Arten der Gattung Colletotrichum. Phytopathol. Z. 29:413-468.

31. Vunsh, R., Rosner, A., and Stein, A. 1990. The use of polymerase chain reaction (PCR) for the detection of bean yellow mosaic virus. Ann. Appl. Biol. 117:561-569.

32. Walcott, R. R. 2003. Detection of seedborne pathogens. Horttechnology 13:40-47.

33. Webster, C. G., Wylie, S. J., and Jones, M. G. K. 2004. Diagnosis of plant viral pathogens. Curr. Sci. 86:1604-1607.

34. White, T. J., Bruns, T., Lee, S., and Taylor, J. 1990. Amplification and direct sequencing of fungal ribosomal RNA genes for phylogenetics. Pages 315-322 in: PCR Protocols. A Guide to Methods and Applications. M. A. Innis, D. H. Gelfand, J. J. Sninsky, and T. J. White, eds. Academic Press, San Diego, CA.

35. Xue, B., Goodwin, P. H., and Annis, S. L. 1992. Pathotype identification of Leptosphaeria maculans with PCR and oligonucleotide primers from ribosomal internal transcribed spacer sequences. Physiol. Mol. Plant Pathol. 141:179-188.

36. Zeng, Q. Y., Hansson, P., and Wang, X. R. 2005. Specific and sensitive detection of the conifer pathogen Gremmeniella abietina by nested PCR. BMC Microbiol. 5:65-73.

37. Zhang, Z., Zhang, J., Wang, Y., and Zheng, X. 2005. Molecular detection of Fusarium oxysporum f. sp. niveum and Mycosphaerella melonis in infected plant tissues and soil. FEMS Microbiol. Lett. 249:39-47. 